\title{
The Effect of Wheatgrass J uice Administration on Physiological State and Oxidative Stress in Carp
}

\author{
GABRIELA DUMITRU ${ }^{1}$, LENUTA DIRVARIU2 ${ }^{2}$ CRISTIAN ALIN BARBACARIU², IONEL MIRON ${ }^{1}$, ION SANDU 3,4 , \\ ELENA TODIRASCU CIORNEA ${ }^{1 *}$ \\ ${ }^{1}$ Alexandru Ioan Cuza University of lasi, Faculty of Biology, Department of Biology, 11 Carol I Blvd., 700506 lasi, Romania \\ ${ }^{2}$ Research and Development Resort for Aquaculture and Aquatic Ecology, Ciurea, Iasi, Romania \\ ${ }^{3}$ Alexandru Ioan Cuza University of lasi, ARHEOINVEST Interdisciplinary Platform, 22 Carol I Blvd., 700506 lasi, Romania \\ ${ }^{4}$ Romanian Inventors Forum, 3 Sf. Petru Movila Str., BI. L11, III/3, 700089 Iasi, Romania
}

\begin{abstract}
The present paper systematizes the results of the research on the effect of wheatgrass juice administration on some important indicators in assessing the physiological state of two summer-old Cyprinus carpio individuals coming from a recirculating system, as well as on some biochemical parameters with role in the antioxidant defensive. For this, an experiment was carried out over a period of 56 days, which consist in growth of 200 carp specimens, with an initial average weight of $72.85 \pm 1.79 \mathrm{~g} / \mathrm{specimen}$. Observations carried out during the entire monitoring period of the experimental variants emphasized a good sanitary status of the studied specimens, accompanied by an active feeding behavior. The results on the activity of oxidative stress enzymes and malon-dialdehyde concentration emphasized significant differences between the treated variants with wheatgrass juice and the control variant, closely related to the wheat juice concentration with which the food ration was supplemented.
\end{abstract}

Keywords: wheatgrass juice, carp, oxidative stress, physiological condition

Wheat is considered to be the agricultural crop with the largest area cultivated worldwide, in our country this crop occupies approximately $25 \%$ of the arable land area and $40 \%$ of the area sown with cereals, wheat flour bread being the main food for a large part of the population.

After 6-10 days of germination, the resulted sprouts form the so-called wheatgrass [1], the juice being rich in vitamins and provitamins, among which vitamins A, C, B1, B6, B12, $\mathrm{E}$, folic acid and b-carotene, antioxidants, minerals such as iron, calcium, magnesium, iodine, selenium, chromium, zinc and phenolic compounds such as ferulic acid, gallic acid, caffeic acid, syringic acid and pcummaric acid [2] and many enzymes and aminoacids [3], which give the wheatgrass juice significant nutritional and medical values $[4,5]$.

On the other hand, Mujoriya, 2011 [6] reported that besides these components, wheatgrass juice is a rich source of vitamin $\mathrm{K}$, sulfur and chlorophyll that neutralizes infections, heals wounds, prevents inflammation, reduces the risk of parasitic infections and strengthens the immune system by inhibiting the metabolic activation of carcinogens [7].

And other authors [8-11] highlight the increasing use of juices from cereal herbs, wheat juice becoming more popular nowadays, being used as a therapeutic food supplement because it improves the immunity of the body and protects it from various health problems.

In addition, it is known as miracle juice or green blood with many therapeutic properties [12-14]. It has anticancer properties [15, 16], antimicrobial [17], lowers blood pressure, is efficacy against diabetes and is hepatoprotective [18], helps to weight loss, is anti-arthritic [19], has antioxidant properties and fights against free radicals that are responsible for damage $[20,21]$.

The goal of this study was to highlight the effects of wheatgrass juice administration on growth performance and biochemical parameters which are implicated in fight against reactive oxygen species on Cyprinus carpio.

\section{Experimental part}

Biological material

The biological material used to evaluate the physiological state was represented by carp specimens with an average weight of $72.85 \pm 1.79 \mathrm{~g} / \mathrm{specimen}$, in the second summer of growth. The experiment was carried out in module 1 of the recirculating system within the Research and Development Resort for Aquaculture and Aquatic Ecology lasi, the module provided with mechanical filter, biological filter and water oxygenation systems.

In vats of $3.14 \mathrm{~m}^{3}$ each, but with a useful water volume of $1.5 \mathrm{~m} 3$, there were 4 experimental variants, in one circular basin with surface water supply and bottom outlet, each batch comprising a number of 50 individuals: a reference batch which receive only fodder (Aller Clasic 2 $\mathrm{mm}$ which contains $30 \%$ brute protein, $7 \%$ lipids, $6.3 \%$ ash, $1 \%$ total $\mathrm{P}, 0.2 \%$ total $\mathrm{Na}, 0.9 \%$ total $\mathrm{Ca}$, vitamins $\mathrm{A}$ and $\mathrm{D}$, $\mathrm{Cu}, \mathrm{Mn}, \mathrm{Zn}, \mathrm{I}$ and antioxidants) and three other lots in which wheat juice was introduced in the daily ration in a concentration of 1,2 and $4 \%$ respectively, which was sprayed directly on the feed. Wheatgrass was obtained by sprouting wheat grains into plastic trays, the crop being regularly watered, and the grass was cut after 10 days from the seed germination. The juice was obtained by squeezing the grass with a juicer. The experiment was carried out between $26.08-20.10 .2017$, at the beginning of it the carp specimens having an appropriate sanitary status.

Biochemical analyzes were performed on muscle and liver tissue taken from 10 individuals from each experimental lot in part, the samples being preserved at $40^{\circ} \mathrm{C}$ until the determinations were performed.

The determination of growth indices and biochemical parameters

In order to assess the health status of the observed fish, were determined a number of physiological indices such as relative growth rate, specific growth rate, feed 
conversion rate, protein efficiency ratio and Fulton coefficient [22-24].

The biochemical tests consisted in the determination of catalase activity by Sinha method, superoxide-dismutase by the Nitro-Blue-Tetrazolium method, glutathioneperoxidase by spectrophotometric method with $5,5^{1}$ dithiobis-2-nitrobenzoic acid and the malon-dialdehyde concentration with 2-thiobarbituric acid [25-27].

For calculation the specific activity, which renders as closely as possible, the real catalytic capacity of the enzymes, we determined the concentration of the total soluble protein using the Bradford method [28].

\section{Statistical interpretation of results}

The experimental data was statistically processed using the Microsoft Excel package, the Anova single factor and the Studenttest. This, the average and the mean standard deviation were calculated, the statistical significance between data being determined by the Fischer test.

\section{Results and discussions}

It is known that from the all components used in fish feed, the most important is protein, but all others are closely linked and lead to normal body development [29-31], in the field being many studies about the cyprinid food and the use of different types of ingredients in recipes feed [ 3234], but also on the use of various vitamin supplements to improve growth parameters in different fish species [3537].

In order to determine the maintenance status of the individuals from the analyzed batches, weekly control fisheries were performed to estimate the increase in length and weight, from each experimental variant being measured and weighed 15 specimens at every check fishing. The sanitary status of the biological material was good throughout the whole experiment, no mortality was recorded, an active feeding behavior being observed.

Thus, the total length (TL) was determined with an intiometer and the individual weight with an analytical balance. The main parameters of growth performance were calculated weekly too, according to the formulas:

- WG (w eight gain, g) = FBW (final body weight, $g$ ) IBW (initial body weight, g) [23];

$-R G R$ (relative growth rate, $\mathrm{g} / \mathrm{g} /$ day) $=[($ final body weight, $g$ - initial body weight, $g$ )/ duration of the experiment) / initial body weight, g] [38];

-SGR (specific growth rate, \%) $=[(\operatorname{lnFBW}-|\ln | B W) /$ number of feeding days] $\times 100$ [39];

$-\mathrm{FCR}$ (feed conversion ratio) $=[$ total feed supplied $\mathrm{g}$ DM/WG (g)] [23];
-PER (protein efficiency ratio) $=[\mathrm{WG}(\mathrm{g}) /$ total protein fed (g/DM)] [39];

$-C F=F B W / T^{3} \times 100[22,24,40]$;

-S (survival rate, $\%$ ) = Number of survive fish / number of fish at the beginning $\times 100$.

The results about the dynamics of the growth rate recorded during the experiment are shown in table 1.

The results obtained from the present research pointed out that, at the start of the study period, statistically the differences are insignificant in terms of both the average weight and length of the specimens from the studied groups $(p>0.05)$.

After the first 7 days from the beginning of the experiment, 15 individuals from each experimental variant were randomly fishing and weighed. The statistical differences are insignificant between all four experimental variants $(p>0.05)$, both in terms of mean weight and length.

After 14 days of treatment, there were significant differences in the case of mean body weight $(p<0.05)$ in the variant where $4 \%$ (V4) wheatgrass juice was added and insignificant differences in the other 3 variants. There were also insignificant differences in the evaluation of the total length, too $(p>0.05)$ as a result of the comparison of all 4 experimental variants.

After 21 days of follow-up, differences between the four experimental variants are again insignificant in both average body weight and length.

At 28 days after the start of the experiment the differences between the control variant (VI) and all three experimental variants are significant $(p<0.05)$, but no significant differences were observed depending on the wheatgrass juice concentration, in what concerns the average body weight and total length comparison.

After 35 days from the first application of wheat juice, the differences are significant $(p<0.05)$ when comparing the control variant (V1) and the experimental variants and insignificant $(p>0.05)$ at the comparison from the variants at which was added wheatgrass juice (V2, V3, V4) in what concerns the average body weight. In the case of total length, there were significant differences $(p<0.05)$ between the variant treated with wheat juice in the concentration of $1 \%(\mathrm{~V} 2)$ and the reference lot (V1), but insignificant for the other lots.

After 42 , respectively 49 days from the start of the experiment, the differences continue to be significant ( $p$ $<0.05$ ) when comparing the control variant (V1) and all the experimental variants and insignificant $(p>0.05)$ at comparing from the variants at which was used wheatgrass juice (V2, V3, V4), in terms of average body weight. In the case of the total length values, at 42 days,

Table 1

THE DYNAMIC OF GROWTH RATE AT EXPERIMENTAL VARIANTS $(n=15 ; \overline{\boldsymbol{x}} \pm$ S.E)

\begin{tabular}{|c|c|c|c|c|c|c|c|c|}
\hline \multirow{2}{*}{ Days } & \multicolumn{2}{|c|}{ V1 } & \multicolumn{2}{|c|}{ V2 } & \multicolumn{2}{|c|}{ V3 } & \multicolumn{2}{|c|}{ V4 } \\
\hline & $\mathrm{G}(\mathrm{g})$ & TL $(\mathrm{cm})$ & $G(g)$ & TL $(\mathrm{cm})$ & $\mathrm{G}(\mathrm{g})$ & TL $(\mathrm{cm})$ & G(g) & $\operatorname{TL}(\mathrm{cm})$ \\
\hline 0 & $74,8^{a} \pm 4.86$ & $17.31^{2} \pm 0.35$ & $75.70^{2} \pm 5.02$ & $17.13^{\mathrm{a}} \pm 0.42$ & $67.71^{a} \pm 2.15$ & $16.95^{2} \pm 0.26$ & $73.19^{\mathrm{a}} \pm 2.1$ & $17.43^{2} \pm 0.31$ \\
\hline 7 & $80.60^{2} \pm 4.48$ & $17.54^{2} \pm 0.29$ & $91.73^{a} \pm 6.49$ & $18.26^{2} \pm 0.35$ & $91.71^{a} \pm 2.58$ & $18.05^{2} \pm 0.23$ & $92.43^{a} \pm 7.01$ & $17.83^{\mathrm{a}} \pm 0.31$ \\
\hline 14 & $102.03^{\mathrm{a}} \pm 5.7$ & $18.28^{\mathrm{a}} \pm 0.39$ & $110.46^{\mathrm{ab}} \pm 5.2$ & $18.47^{\mathbf{a}} \pm 0.24$ & $103.19^{\mathrm{ab}} \pm 6.01$ & $18.55^{\mathrm{a}} \pm 0.33$ & $117.05^{b} \pm 3.8$ & $18.39^{\mathrm{a}} \pm 0.26$ \\
\hline 21 & $120.97^{a} \pm 6.5$ & $18.30^{\mathrm{a}} \pm 0.65$ & $138.74^{\mathrm{a}} \pm 8.6$ & $19.46^{\mathrm{a}} \pm 0.37$ & $133.61^{\mathrm{a}} \pm 7.84$ & $19.06^{2} \pm 0.32$ & $138.46^{a} \pm 5.8$ & $19.12^{\mathrm{a}} \pm 0.27$ \\
\hline 28 & $137.09^{\mathrm{a}} \pm 8.1$ & $19.03^{a} \pm 0.35$ & $165.67^{b} \pm 8.8$ & $21.61^{b} \pm 0.64$ & $163.12^{b} \pm 8.50$ & $20.25^{b} \pm 0.32$ & $173.80^{b} \pm 11.3$ & $20.62^{b} \pm 0.4$ \\
\hline 35 & $142.16^{2} \pm 9.7$ & $20.01^{2} \pm 0.44$ & $180.8^{b} \pm 15.1$ & $21.20^{b} \pm 0.61$ & $195.33^{b} \pm 10.72$ & $21.48^{\mathrm{ab}} \pm 0.30$ & $185.87^{b} \pm 12.1$ & $21.21^{\mathrm{ab}} \pm 0.41$ \\
\hline 42 & $180.92^{2} \pm 9.3$ & $20.64^{\mathrm{a}} \pm 0.30$ & $199.2^{b} \pm 19.1$ & $21.20^{\mathrm{ab}} \pm 0.6$ & $232.60^{\mathrm{b}} \pm 12.23$ & $22.33^{b} \pm 0.28$ & $226.16^{\mathrm{b}} \pm 12.7$ & $22.05^{\mathrm{b}} \pm 0.24$ \\
\hline 49 & $211.5^{\mathrm{a}} \pm 15.6$ & $22.15^{\mathrm{a}} \pm 0.61$ & $273.7^{\mathrm{b}} \pm 15.1$ & $23.76^{\mathrm{b}} \pm 0.44$ & $252.17^{\mathrm{b}} \pm 13.48$ & $23.30^{\mathrm{ab}} \pm 0.30$ & $264.51^{b} \pm 18.2$ & $23.05^{\mathrm{ab}} \pm 0.43$ \\
\hline 56 & $228.9^{2} \pm 13.6$ & $23.24^{2} \pm 0.5$ & $279.7^{\mathrm{sc}} \pm 16.9$ & $24.3^{25} \pm 0.38$ & $317.3^{50} \pm 12.3$ & $24.90^{2} \pm 0.23$ & $336.2^{\mathrm{d}} \pm 18.06$ & $25.44^{b} \pm 0.42$ \\
\hline
\end{tabular}

V1 = reference; V2 = the batch treated with $1 \%$ juice wheat; V3 = the batch treated with $2 \%$ juice wheat; $\mathrm{V} 4=$ the batch treated with $4 \%$ juice wheat

Note: Values (mean $\pm \mathrm{SE}$ ) in the same row not sharing a common superscript letter are significantly different $(\mathrm{p}<0.05)$ 
the differences were significant $(p<0.05)$ between the control variant (V1) and the V3 and V4 variants and insignificant $(p<0.05)$ among the others, while at 49 days, the differences are significant $(p<0.05)$ between the reference variant (V1) and the second variant (V2) and insignificant $(p>0.05)$ among the others.

At the last control fishing, of 56 days of application of wheat juice, in terms of average body weight, the differences between the control variant and the experimental variants are significant, with significant differences between the variant containing the maximum juice concentration and the variant $1 \%$. When comparing the total length values the differences are significant $(p<$ 0.05 ) between the control variant (V1) and the batches with $2 \%$ and $4 \%$ wheat juice and insignificant ( $p>0.05$ ) among the others.

Based on the statistical interpretation of the growth performance indicators, it can be noticed that the differences are insignificant in what concerns the initial weight $(p>0.05)$. The mean final weight shows that, statistically, the differences are significant $(p<0.05)$ between the control variant (V1) and the variants V2, V3, V4, as well as between variants V2 and V4 and insignificant between variants V 2 and $\mathrm{V} 3$, respectively V 3 and $\mathrm{V} 4$ (table 2).

Regarding the relative grow th rate (RGR), following the interpretation of statistical data, it can be noticed that the differences are insignificant ( $p>0.05$ ) between all experimental variants.

The specific growth rate (SGR) had high values, the statistical differences being significant $(p<0.05)$ between the reference group and the treated samples, but also between variants V 2 and V3, respectively V 3 and V4 and insignificant $(p>0.05)$ between variants V2 and V4.

Analysis of the statistical results on protein efficiency ratio shows the existence of significant differences ( $p<$ 0.05 ) between the untreated group and the other experimental variants and insignificant $(p>0.05)$ between variants V2 and V3, respectively V2 and V4.

The feed conversion factor (FCR) was higher in the reference group (V1) and was inversely proportional to PER. Statistical differences were significant $(p<0.05)$ between the control variant (V1) and the other variants and between variants V3 and V4, but insignificant $(p>0.05)$ between $\mathrm{V} 2$ and $V 3$, respectively V2 and V4.

This shows that wheatgrass juice influences the absorption capacity of nutrients, improving this process, which ultimately leads to better growth. By comparison, research by Al-Faragi and Al-Saphar, 2013 [39] which investigate the probiotic use in carp nutrition obtain, using a feed of $26 \%$ protein, a conversion of 7.2 in the control group decreasing up to 3.49 when administered additional probiotics in the proportion of $0.25 \mathrm{~g} / \mathrm{kg}$ of feed.

Condition factor (CF) reflects the physiological condition or so-called general condition of the organism, so that the high values of this index indicate a state of harmonious development [40].

In the study we initiated, the Fulton coefficient had high values, but did not show statistical differences between the experimental variants, which were insignificant ( $p$ > 0.05).

The condition factor showed high values compared to the studies in the field, the minimum being 1.84 corresponding to the experimental variant $\mathrm{V} 2$, and the maximum being of 1.97 corresponding to the experimental variant $V 4$. By comparison, studies conducted by Keyombe, 2017 [43] show a condition factor of 1.51 at Cyprinus carpio in Lake Naivasha, Kenya, in Ethiopia carp [44] was of 1.22, and in South-West of the Caspian Sea [45] the condition factor was equal to 1.34. We can say that the specimens in the whole lot studied can be classified as being in an excellent state of maintenance.

Another objective of our study was to analyze the effect of wheat juice in concentrations of 1,2 and $4 \%$, respectively, both on the activity of oxidative stress enzymes and on the level of lipid peroxidation, literature data [46, 47], highlighting that wheat juice is rich in antioxidant enzymes such as superoxide-dismutase (SOD) and cytochrome oxidase that have the potential to convert reactive oxygen species (ROS) to hydrogen peroxide and molecular oxygen.

Thus, a first enzyme taken in the study was superoxidedismutase (superoxide: superoxide - oxidoreductase, EC 1.15.1.1) oxidoreductase involved in the conversion of superoxide radicals $[48,49]$. From figure 1 it can be

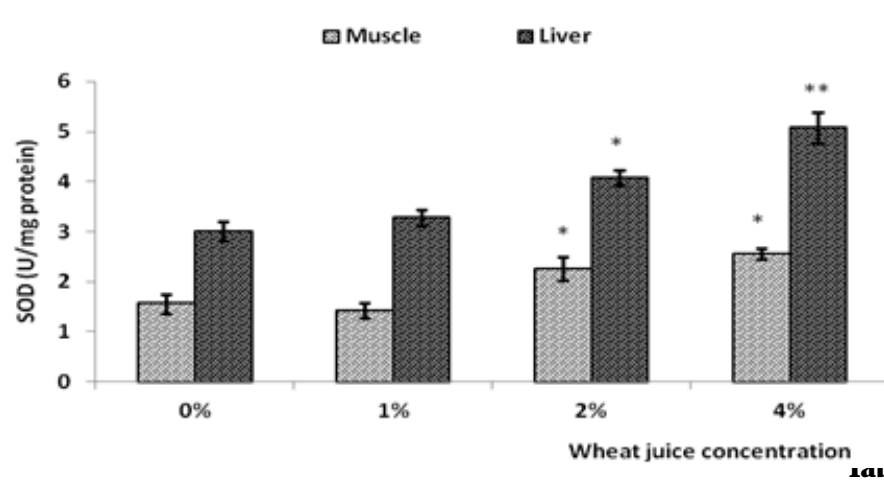

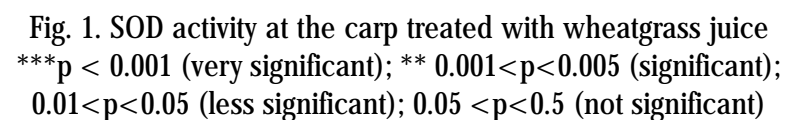

THE GROWTH PARAMETERS AT EXPERIMENTAL VARIANTS ( $\mathrm{n}=15 ; \overline{\boldsymbol{x}} \pm \mathrm{S} . \mathrm{E})$

\begin{tabular}{|c|c|c|c|c|c|c|c|c|}
\hline Variant & IBW & FBW & RGR & SGR & PER & FCR & CF & $\mathrm{S}$ \\
\hline V1 & $74.80^{2} \pm 4.86$ & $228.97^{\mathrm{a}} \pm 13.61$ & $0.07^{2} \pm 0.01$ & $1.97^{2} \pm 0.14$ & $1.47^{2} \pm 0.11$ & $2.39^{a} \pm 0.36$ & $1.85^{\mathrm{a}} \pm 0.07$ & 96 \\
\hline $\mathrm{V} 2$ & $75.70^{2} \pm 5.02$ & $279.73^{b c} \pm 16.96$ & $0.8^{a} \pm 0.01$ & $2.59^{\mathrm{bc}} \pm 0.08$ & $2.33^{b c d} \pm 0.10$ & $1.44^{\mathrm{bd}} \pm 0.07$ & $1.84^{2} \pm 0.07$ & 98 \\
\hline V3 & $67.71^{2} \pm 2.15$ & $317.34^{\mathrm{bd}} \pm 12.03$ & $0.10^{2} \pm 0.01$ & $3.11^{\mathrm{d}} \pm 0.16$ & $2.44^{\mathrm{C}} \pm 0.14$ & $1.39^{b c} \pm 0.07$ & $1.89^{2} \pm 0.07$ & 96 \\
\hline V4 & $80.53^{2} \pm 4$ & $336.28^{\mathrm{d}} \pm 18.06$ & $0.9^{\mathrm{a}} \pm 0.01$ & $2.47^{\text {ec }} \pm 0.08$ & $2.08^{\mathrm{d}} \pm 0.07$ & $1.62^{\mathrm{d}} \pm 0.06$ & $1.97^{2} \pm 0.06$ & 98 \\
\hline
\end{tabular}

$\mathrm{V} 1=$ reference; $\mathrm{V} 2=$ the batch treated with $1 \%$ juice wheat; V3 = the batch treated with $2 \%$ juice wheat;

$\mathrm{V} 4=$ the batch treated with $4 \%$ juice wheat; IBW = initial body weight $(\mathrm{g}) ; \mathrm{FBW}=$ final body weight $(\mathrm{g})$;

$\mathrm{RGR}=$ relative growth rate $(\mathrm{g} / \mathrm{g} /$ day $) ; \mathrm{SGR}=$ specific growth rate $(\%) ; \mathrm{PER}$ protein efficiency ratio

( $g /$ dry matter); FCR = feed conversion ratio ( $g$ dry matter/g weight gain);

$\mathrm{CF}=$ Fulton coefficient; $\mathrm{S}=$ survival rate $(\%)$

Note: Values (mean $\pm \mathrm{SE}$ ) in the same row not sharing a common superscript 
observed that SOD has a much higher activity in liver tissue compared to muscle tissue. If in the control group, the superoxide-dismutase activity in the muscle reached the mean value of $1.563 \pm 0.188 \mathrm{USOD} / \mathrm{mg}$ protein, in the sample treated with $1 \%$ wheat juice, the enzyme showed a slight decrease in activity to the $1.426 \pm 0.144$ USOD $/ \mathrm{mg}$ protein, so that at $2 \%$ and $4 \%$ wheat juice concentrations, respectively, to register levels of $2.262 \pm 0.237 \mathrm{USOD} / \mathrm{mg}$ protein, respectively $2.558 \pm 0.113$ USOD/mg protein.

In the case of hepatic tissue, it can be noticed that regardless of the wheat juice concentration administered, SOD has a higher activity compared to the untreated variant. In fact, the statistical analysis of the results indicates the existence of significant differences between the reference group (3.011 $\pm 0.193 \mathrm{USOD} / \mathrm{mg}$ protein) and the batch treated with a maximum concentration of wheat juice $(5.073 \pm 0.311$ USOD/mg protein).

Catalase (CAT) is a tetrameric chromoprotein found from bacteria and fungi to the most complex animal organisms $[50,51]$ and plays a role in protecting cells from the toxic effects of hydrogen peroxide which it mobilizes at high speed to convert to $\mathrm{O}_{2}$ and $\mathrm{H}_{2} \mathrm{O}$ without producing other free radicals [52].

The analysis of experimental results on CAT activity highlights a wide range of values both between the experimental groups and between the two types of tissue studied (fig. 2). Thus, in muscle tissue, CAT activity varies
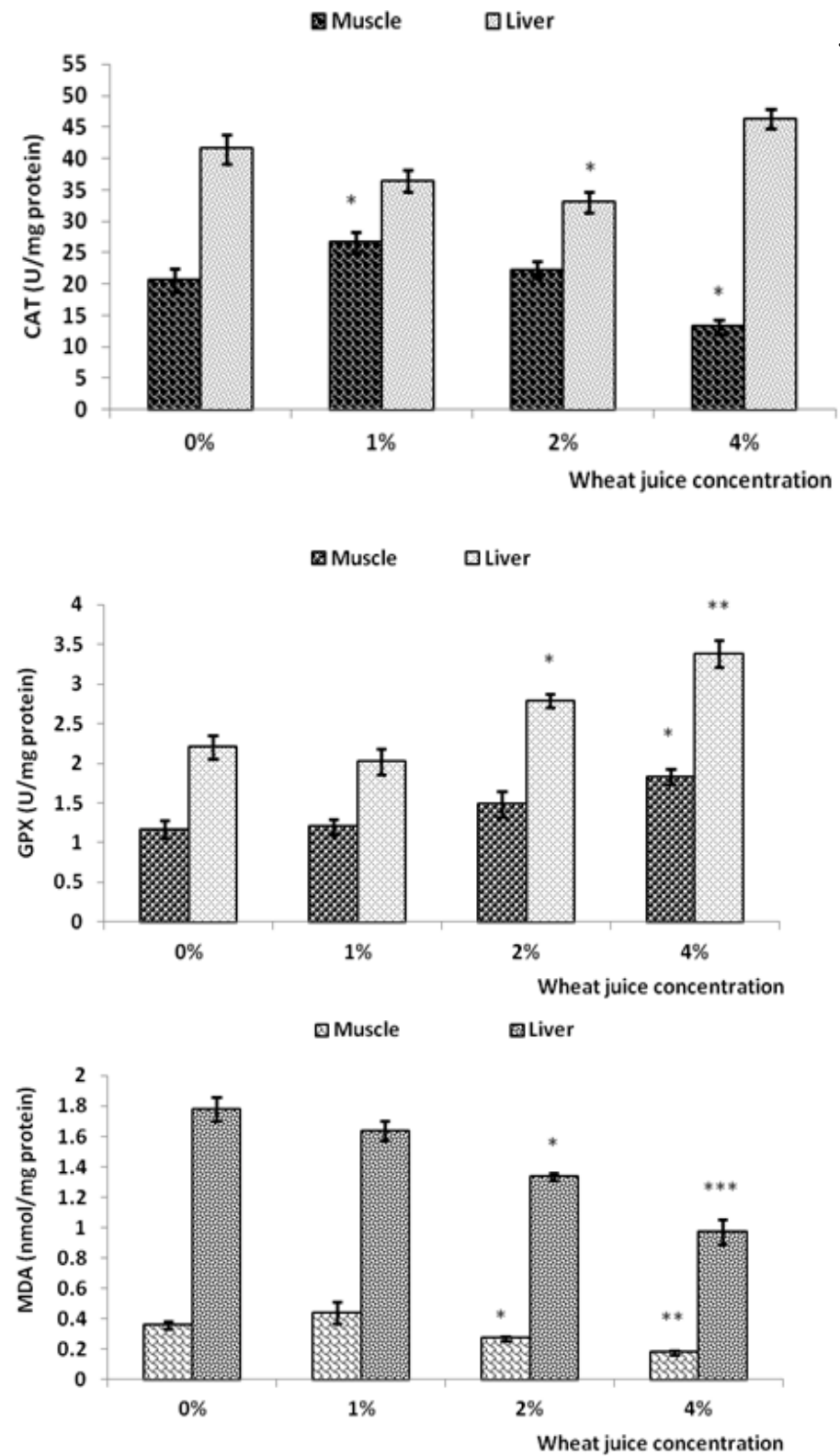

REV.CHIM.(Bucharest) 69 No. $11 \bullet 2018$ between $13.193 \pm 1.205 \mathrm{UCAT} / \mathrm{mg}$ protein in the $4 \%$ wheat juice variant and $26.716 \pm 1.636 \mathrm{UCAT} / \mathrm{mg}$ protein in the $1 \%$ wheat juice group. In liver tissue, CAT activity recorded a threshold of $36.406 \pm 1.734 \mathrm{UCAT} / \mathrm{mg}$ protein in variant 2 , $33.03 \pm 1.583 \mathrm{UCAT} / \mathrm{mg}$ protein in variant V3 and a maximum threshold of $46.333 \pm 1.519 \mathrm{UCAT} / \mathrm{mg}$ protein in the variant treated with wheat juice $4 \%$.

GPX is an antioxidant intracellular enzyme present in blood plasma, erythrocytes and various animal tissues which catalyze the reduction of hydrogen peroxide in water and lipid hydroperoxides at the corresponding alcohols to limit its harmful effects [53].

At the muscular level, as shown in figure 3, GPX records an average activity of 1.171 $0.11 \mathrm{UGPX/mg}$ protein in the reference experimental variant, so that whenever a wheat juice concentration of 2 and $4 \%$ the GPX free mobilization rate is higher $(1.492 \pm 0.16 \mathrm{UGPX} / \mathrm{mg}$ protein and $1.833 \pm 0.103 \mathrm{UGPX} / \mathrm{mg}$ protein) compared to the control group. In contrast, in the case of hepatic tissue, GPX has a minimum threshold for the batch treated with $1 \%$ wheat juice (2.028 $\pm 0.163 \mathrm{UGPX} / \mathrm{mg}$ protein), so that in the variant treated with $2 \%$ wheat juice it reaches an average value of $2.794 \pm 0.083 \mathrm{UGPX} / \mathrm{mg}$ protein, the maximum value being registered in the case of the fish who were feed with $4 \%$ wheat juice (3.384 $\pm 0.168 \mathrm{UGPX} / \mathrm{mg}$ protein).

In addition, the $t$-Student statistical significance test revealed a significant difference $(0.01<p<0.05)$ between the control group and the variant treated with $4 \%$ wheat juice in the case of hepatic samples.

Fig. 2. CAT activity at the carp treated with wheatgrass juice $* * * p<0.001$ (very significant); $* * 0.001<p<0.005$ (significant); $* 0.01<p<0.05$ (less significant); $0.05<p<0.5$ (not significant)

Fig. 3. GPX activity at the carp treated with wheatgrass juice $* * * p<0.001$ (very significant); ** $0.001<p<0.005$ (significant); $* 0.01<p<0.05$ (less significant); $0.05<p<0.5$ (not significant)

Fig. 4. MDA concentration at the carp treated with wheatgrass juice ${ }^{* * *} p<0.001$ (very significant); $* * 0.001<p<0.005$ (significant); $* 0.01<p<0.05$ (less significant); $0.05<p<0.5$ (not significant) 
Literature data [1] indicates that antioxidants are essential compounds in foods that are very efficiency in preventing body-damaging reactions, such as oxidation of lipids caused by oxidative stress, malon-dialdehyde (MDA) being a marker of oxidative stress and oxidative status of the animal and human organism [54].

In what concerns the MDA concentration in liver tissue samples, at the two summer-old carp groups subjected to wheat juice treatment (fig. 4) show a decreasing trend from the reference lot to the maximum juice concentration of the wheat administered, the application of the Student statistical significance test showing the existence of very significant differences between the sample treated with $4 \%$ wheat juice $(0.917 \pm 0.081 \mathrm{nM} / \mathrm{mg}$ protein) and the reference $(1.778 \pm 0.078 \mathrm{nM} / \mathrm{mg}$ protein). In the case of muscle tissue, related hepatic samples, the minimum MDA concentration is also recorded for V4 variant $(0.178 \pm 0.013$ $\mathrm{nM} / \mathrm{mg}$ protein), while the maximum threshold is reached for the batch treated with $1 \%$ wheat juice $(0.44 \pm 0.074$ $\mathrm{nM} / \mathrm{mg}$ protein).

\section{Conclusions}

On the basis from experimental data it can be stipulated the following conclusions:

The growth rate obtained and the state of maintenance of the fish in the case of wheatgrass juice administration are significantly higher compared to the control variant.

In addition to a faster growth rate, wheatgrass juice administration also influences the specific growth rate feed conversion factor, feed protein efficiency, and general maintenance status, expressed by the condition factor.

Survival was good for all experimental variants, being between $96-98 \%$.

In terms of the activity of oxidative stress enzymes and malon-dialdehyde level, more or less significant differences were found between the reference group and the experimental variants, irrespective of the concentration of wheatgrass juice administered. In the same time, significant differences were also noted depending of the tissue analyzed, with higher net values in the case of the liver.

\section{References}

1.AKBAS, E., KILERCIOGLU, M., ONDER, O.N., KOKER, A., SOYLER, B., OZTOP, M.H., Journal of Functional Foods, 28, 2017, p. 19. 2. BENINCASA, P., GALIENI, A., MANETTA, A.C., PACE, R., GUIDUCCI, M., PISANTE, M., STAGNARI, F., Journal of the Science of Food and Agriculture, 95, 2015, p. 1795.

3.STOICA, R., SENIN, R., RADU, E., MANOLACHE, M., OANCEA, F., CEAUSU, M., Rev. Chim. (Bucharest), 67, no. 9, 2016, p. 1669.

4. PATEL, J.B., J ournal of Drug Delivery \& Therapeutics, 6, no. 3, 2016, p. 84.

5. REBEKIC, A., LISJ AK, M., MISKOVIC SPOLJARIC, K., GUBERAC, S., ORKIC, V., Project: Genotype specificity of wheatgrass (Triticum aestivum L.) highly nutritional natural food supplement, Rozman, V. \& Antunovic, Z. (Editors), Zbornik radova 53. Hrvatski i 13. Meðunarodni simpozij agronoma. Osijek, Poljoprivredni fakultet u Osijeku, pp. 211-215.

6. MUJ ORIYA, R., BODLA, R.B., Food Science and Quality Management, 2, 2011, p. 1.

7. AYDOS, O., AVCI, A., OZKAN, T., KARADAG, A., GURLEYIK, E., Turkish J ournal of. Medical Science, 41, no. 4, 2011, p. 657.

8.HASANI, A., KONGOLI, R., PECULI, A., KOKTHI, E., International J ournal of Agriculture and Environmental Research, 2, no. 4, 2016, p. 699.

9. OZKOSE, A., ARSLAN, D., ACAR, A., Not. Bot. Horti. Agrobo., 44, no. 2, 2016, p. 499.

10. KASHUDHAN, H., DIXIT, A., UPADHYAY, A., Journal of Pharmacognosy and Phytochemistry, 6, no. 2, 2017, p. 338.
11. KABEER, B., ANWAR, M., RAIS, M., JILANI, M.J ., ASADI, M.A., ABID, S., BILAL, S., SALEEM, F., AHMED, B.H., YUNUS, A.W., ZAHID, S., ANJUM, M., HEJ CMANOVA, P., SHEIKH, M.K., MEHMOOD, A., International J ournal of Conservation Science, 9, no. 2, 2018, p. 337. 12. DE-VOGEL, J., JONKER-TERMON, D.S.M.L., VAN LIESHOUT, E.M., KATAN, M.B., VANDER, M.R., Carcinogenesis, 26, no. 2, 2005, p. 387. 13. KOTHARI, S., J AIN, A.K., MEHTA, S.C., TONPAY, S.D., Indian J. Pharmacol., 40, no. 5, 2008, p. 235.

14. SWATI, P., SUSHMA, D., INDIRA, R., ALKA, G., MAMTA, D., Chronicles of young scientists, 1, no. 2, 2010, p. 23.

15. SHARMA, R.M., NAIR, A.T., HARAK, S.S., PATIL, T.D., SHELKE, S.P., World Journal of Pharmacy and Pharmaceutical Sciences, 5, no. 7, 2016, p. 384.

16. GORE, R.D., PALASKAR, S.J ., RATNADEEP BARTAKE, A., Journal of Clinical and Diagnostic Research, 11, no. 6, 2017, p. 40.

17. SAHA, S., ISLAM, Z., ISLAM, S., HOSSAIN, S., ISLAM, S.M.S., SKUAST Journal of Research, 20, no.1, 2018, p. 58.

18. DURAIRAJ, V., SHAKYA, G., RAJ AGOPALAN, R., J ournal of Dietary Supplements, 12, 2015, p. 126.

19. CHAUHAN, M., International Journal of Chemical Studies, 2, no. 4, 2014, p. 27.

20. KULKARNI, S., TILAK, J., ACHARYA, R., RAJURKAR, N., DEVASAGAYAM, T., REDDY, A., Phytother. Res., 20, 2006, p. 218.

21. DAS, P., MUKHOPADHY, A., MANDAL, S., CHANDRA. B., MISHRA, R., MUKHERJEE, D., MUKHOPADHYAY, S., BASAK, J ., KAR, M., Europ. J. Medic. Plants, 2, 2012, p. 113.

22. NASH, R., VALENCIA, A., GEFFEN, A., Fisheries, 31, 2006, p. 236.

23. XU, W., GAO, Z., QI, Z., QIU, M., PENG, J.Q., SHAO, R., Turkish J ournal of Fisheries and Aquatic Sciences, 14, 2014, p. 53.

24. KHARA, H., SAYYAD BORANI, M., SAYYAD BORANI, M., Turkish J ournal of Fisheries and Aquatic Sciences, 16, 2016, p. 385.

25. DOBRIAN, A.D., DAVIES M.J., SCHRIVER S.D., LAUTERIO T.J., PREWITT R.L., Hypertension, 37, 2001, p. 554-560

26. COJOCARU, D.C., Enzimologie practica, Ed. Tehnopress, Iasi, 2005, p. 148-150

27. PINTILIE, O., ION, L., SURLEVA, A., ZAHARIA, M., TODIRASCU CIORNEA, E., CIUBOTARIU, E., BALAN, A., DROCHIOIU, G., SANDU, I., Rev. Chim. (Bucharest), 67, no. 4, 2016, p. 687.

28. TODIRASCU CIORNEA, E., DUMITRU, G., SANDU, I., Rev. Chim. (Bucharest), 69, no. 8, 2018, p. 2160.

29. KIKUCHI, K., J ournal of the World Aquaculture Society, 30, 1999, p. 357.

30. KIKUCHI, K., Aquaculture, 179, 1999, p. 3.

31. NONGMAITHEM, R., LODHI, M.S., SAMAL, P.K., DHYANI, P.P., SHARMA, S., International J ournal of Conservation Science, 7, no. 2, 2016, p. 523.

32. MOLNAR, F., SARA, A., GABOR, E.F., BENTE, M., Animal Science and Biotechnologies, 44, no. 2, 2011, p. 24.

33. GHADERI, R.F., JAHANBAKHSHI, A., SOUDAGAR, M., Journal of Fisheries Science and Technology, 1, no. 1, 2013, p. 53.

34. BOCIOC, E., CRISTEA, V., PATRICHE, N., GRECU, I., ION, S., MOCANU, M., COADA, M.T., Scientific Papers-Animal Science Series: Lucrari Stiintifice - Seria Zootehnie, 63, 2015, p. 1454.

35. MOEIN, F., Global Veterinaria, 8, no. 5, 2012, p. 507.

36. MERCHIE, G., LAVENS, P., SORGELOOS, P., Aquaculture, 155, 1997, p. 165.

37. NICA, A., VASILEAN, I., POPESCU, A., IBANESCU, D.C., Scientific Papers-Animal Science Series: Lucrari Stiintifice - Seria Zootehnie, 66, 2016, p. 170.

38. PETREA, S., MOGODAN, A., METAXA, I., PLACINTA, S., VASILE, M., HUIAN, G., AACL Bioflux, 10, no. 1, 2017, p. 87.

39. HELLAND, S.)., HELLAND, G., NERLAND, S., Aquaculture, 139, 1996, p. 157.

40. GONZALEZ-RODRIGUEZ, A., CELADA, J.D., CARRAL, J.M., SAEZROYUELA, M., FUERTES, J.B., Anim. Feed. Sci .Technol., 187, 2014, p. 61.

41. AL-FARAGI, J.K.H., AL-SAPHAR, S.A.A., J ournal of Genetic and Environmental Resources Conservation, 1, no. 2, 2013, p. 89. 
42. DUMITRU, G., TODIRASCU CIORNEA, E., HRITCU, L., SANDU, I.G., Rev. Chim. (Bucharest), 69, no. 5, 2018, p. 1194.

43. KEYOMBE, J.L., ANDREW, Y.W., DALMAS, O.O., Int. J. Aquat. Biol., 5, no. 3, 2017, p. 228.

44. HAILU, M., Journal of Ecology and the Natural Environment, 5, no. 9,2013 p. 260.

45. MORADINASAB, G., DALIRI, M., GHORBANI, R., PAIGHAMBARI, S.Y., DAVOODI, R., Caspian J. Environ. Sci., 10, no. 1, 2012, p. 25.

46. PADALIA, S., DRABU, S., RAHEJ A, I., GUPTA, A., DHAMIJA, M., Chronicles of Young Scientists, 1, no. 2, 2010, p. 23.

47. DURAIRAJ, V., HODA, M., SHAKYA, G., PREEDIA BABU, S.P., RAJ AGOPALAN, R., Asian Pacific J ournal of Tropical Medicine, 7, Suppl 1, 2014, p. S398.

48. FRIDOVICH, I., J. Biol. Chem., 264, 1989, p. 7761.

49. PEIXOTO, F., CARROLA, J., COIMBRA, A.M., FERNANDES, C., TEIXEIRA, P., COELHO, L., CONCEICAO, I., OLIVEIRA, M.M., FONTAINHAS-FERNANDES, A., Rev. Int. Contam. Ambie., 29, no. 1, 2013, p. 29.
50.DIAZ-ALBITER, H., MITFORD, R., GENTA, F.A., SANTANNA, M.R.V., DILLON, R.J., PLOS ONE, 6, no. 3, 2011, Paper no. e17486, https:// doi.org/10.1371/journal.pone.0017486

51.De MAGALHAES, C.S., TAKARADA, J.E., COSTA, CARVALHO, N., CARVALHO, D.C., DE ANDRADE, F.L., BATISTA FERREIRA, E., LUCCAS, P.O., AZEVEDO, L., J ournal of Chemistry, 2016, 2016, Article ID 8570321, http://dx.doi.org/10.1155/2016/8570321

52.ODAJ IMA, N., BETSUYAKU, T., NAGAI, K., MORIYAMA, C., WANG, D., TAKIGAWA, T., OGINO, K., NISHIMURA, M., Respiratory Research, 11, no. 1, 2010, p. 183.

53.LUBOS, E., LOSCALZO, J., HANDY, D.E., Antioxid. Redox Signal., 15, no. 7, 2011, p. 1957.

54.AYALA, A., MUNOZ, M.F., ARGUELLES, S., Oxidative Medicine and Cellular Longevity, 2014, 2014, Article ID 360438, http://dx.doi.org/ $10.1155 / 2014 / 360438$

Manuscript received: 4.05 .2018 